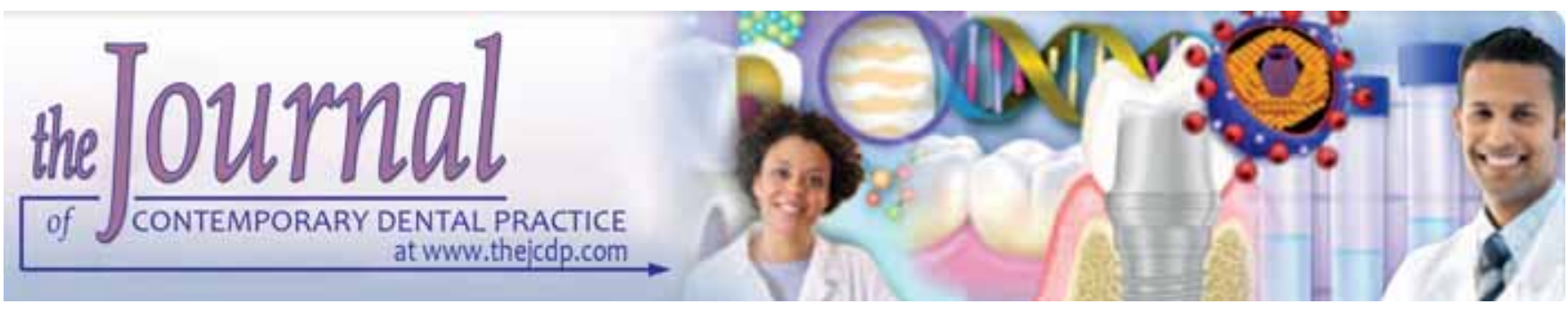

\title{
Evaluation of Residual Antimicrobial Effects and Surface Changes of Gutta-Percha disinfected with Different Solutions
}

\author{
G Şahinkesen, EA Oktay, Ö Er, MM Koçak, A Kiliç
}

\begin{abstract}
Aim: To determine the possible residual antibacterial effects and possible surface changes caused by $5.25 \% \mathrm{NaOCl}, 2.5 \%$ $\mathrm{NaOCl}, 2 \% \mathrm{CHX}$ and $0.05 \%$ Octenisept on in vitro gutta-percha points after different disinfection protocols.
\end{abstract}

Materials and methods: A total of 121 standard \# 40, 0.2\% gutta-percha cones were cut $10 \mathrm{~mm}$ from the tip, sterilized with ethylene oxide. The samples were divided into five groups, and each group was divided into three subgroups according to immersion periods of gutta-percha cones into solutions. One gutta-percha cone from each group was selected for SEM evaluation.

Results: All of the tested solutions were effective on the selected microorganisms when compared with the control solution. No surface alterations were detected on the gutta-percha cones.

Conclusion: In the limits of this study, immersion of gutta-percha into $2 \% \mathrm{CHX}$ for one minute was found the most effective method to eliminate the selected microorganisms.

Clinical significance: Although gutta-percha points are aseptic in their package, once opened and used, gutta-percha cones may be contaminated. In order to eliminate bacteria and not to cause surface changes on gutta-percha cones, disinfection solution must be selected carefully.

Keywords: Chlorhexidine, Gutta-percha disinfectants, Octenidine hydrochloride, Sodium hypochlorite.

How to cite this article: Şahinkesen G, Oktay EA, Er Ö, Koçak MM, Kiliç A. Evaluation of Residual Antimicrobial Effects and Surface Changes of Gutta-Percha disinfected with Different Solutions. J Contemp Dent Pract 2011;12(1):47-51.

Source of support: Nil

Conflict of interest: None declared

\section{INTRODUCTION}

The goal of endodontic therapy can be achieved by an accurate diagnosis followed by successful entrance, cleaning and shaping of the root canal system, and filling. Among these procedures, the priority is to eliminate microbial contamination. ${ }^{1}$
Since its introduction in endodontics over 100 years ago, gutta-percha cones have been the most commonly used material for filling root canals. They are biocompatible, dimensionally stable, radiopaque, and thermoplastic. ${ }^{2}$ Although most endodontic instruments can be sterilized by autoclaving or by dry heat procedures, because of its thermoplastic behavior, gutta-percha cannot be sterilized with thermal-related conventional techniques. Even though the gutta-percha cones are manufactured under aseptic conditions, most manufacturers do not claim that their guttapercha cones are sterile and gutta-percha cones can also be contaminated by handling, by aerosols and during the storage process. ${ }^{3,4}$ Therefore, studies about gutta-percha disinfection have evaluated several chemical cold disinfection solutions, such as polyvinylpyrrolidone-iodine, ethyl alcohol, sodium hypochlorite $(\mathrm{NaOCl})$, hydrogen peroxide, glutaraldehyde, and chlorhexidine (CHX) ${ }^{5-8}$

Among the various methods, immersing gutta-percha into $5.25 \%$ of $\mathrm{NaOCl}$ for $1 \mathrm{~min}$ is a good standard for rapid decontamination of gutta-percha. ${ }^{7,9}$ However, it was reported that $5.25 \% \mathrm{NaOCl}$, a strong oxidizing agent, may cause topographic alterations to gutta-percha cones and failure of endodontic obturation. ${ }^{10} \mathrm{CHX}$ also has an increasing popularity in endodontics by its antimicrobial efficiency. ${ }^{11} \mathrm{CHX}$ was also found as an effective guttapercha disinfectant and showed no surface alterations. ${ }^{12}$ Octenisept is an antiseptic for skin burns, wound disinfection and mouth rinses consisting of octenidine hydrochloride and phenoxyethanol. ${ }^{13}$ Octenidine hydrochloride demonstrates broad spectrum antimicrobial effects covering both gram-positive and gram-negative bacteria, fungi and several viral species. ${ }^{14}$

The aim of this study was to evaluate possible residual antibacterial effects of $5.25 \% \mathrm{NaOCl}, 2.5 \% \mathrm{NaOCl}, 2 \%$ CHX and $0.05 \%$ octenisept on Staphylococcus aureus, 
Enterococcus faecalis when used as a gutta-percha disinfectant and to evaluate the possible surface alterations of solutions on gutta-percha points.

\section{MATERIALS AND METHODS}

A total of 121 standard \# 40, 0.2\% gutta-percha cones (VDW, GmbH, München, Germany) were cut $10 \mathrm{~mm}$ from the tip, sterilized with ethylene oxide and used in this study. The samples were divided into five groups, and each group was divided into three subgroups, as follows:

- Group 1: Seven cones per subgroup were immersed in $5 \mathrm{ml}$ of $5.25 \% \mathrm{NaOCl}$ for 1 minute (subgroup I), 5 minutes (subgroup II) or 10 minutes (subgroup III).

- Group 2: Seven cones per subgroup were immersed in $5 \mathrm{ml}$ of $2.5 \% \mathrm{NaOCl}$ for 1 minute (subgroup I), 5 minutes (subgroup II) or 10 minutes (subgroup III).

- Group 3: Seven cones per subgroup were immersed in $5 \mathrm{ml}$ of 2\% CHX (Drogsan, Cubuk, Ankara, Turkey) for 1 minute (subgroup I), for 5 minutes (subgroup II) or for 10 minutes (subgroup III).

- Group 4: Seven cones per subgroup were immersed in $5 \mathrm{ml}$ of $0.05 \%$ octenisept (Schülke and Mayr, GmbH, Norderstedt, Germany) for 1 minute (subgroup I), for 5 minutes (subgroup II) or for 10 minutes (subgroup III).

- Group 5 (positive control group): Seven cones per subgroup were immersed in $5 \mathrm{ml}$ of sterile saline solution (Vacoliter, Eczacıbaşi- Baxter, Ayazağa, İstanbul, Turkey) for 1 minute (subgroup I), for 5 minutes (subgroup II) or for 10 minutes (subgroup III).

All chemicals were of high-grade purity and had a minimum of 12 months before the expiration date. After removal from the test solutions, the cones were dried with sterile gauze. Each cone was immediately added to the surface of the media for microbiologic testing after removal from the test solutions and drying process.

\section{AGAR DIFFUSION TEST}

The species of microorganisms used in this study were Staphylococcus aureus ATCC 25923 and Enterococcus faecalis ATCC 29212.

A modified Kirby Bauer disk diffusion method was used to evaluate zone size of the gutta-percha cones disinfected with different antimicrobial solutions. ${ }^{15}$ The isolates were grown overnight on a nonselective medium at $35^{\circ} \mathrm{C}$. Bacterial inocula were prepared by suspending the freshly grown bacteria in sterile normal saline adjusted to a 0.5 McFarland Standard (approximately 1 to $2 \times 10^{8} \mathrm{CFU} / \mathrm{mL}$ ). The suspensions were inoculated onto $9 \mathrm{~cm}$. The guttapercha cones were pressed lengthwise into the agar surface. Mueller-Hinton agar plates were incubated at $35^{\circ} \mathrm{C}$ in ambient air at least for 16 to 18 hours. After incubation, zone size was assessed by measuring the diameter perpendicular to the long axis of the gutta-percha.

\section{SCANNING ELECTRON MICROSCOPE (SEM)}

A total number of 16 standard \# 40, gutta-percha cones were immersed into test solutions (except one for control) and analyzed by scanning electron microscope (JEOL, JSM 6360 LV, Tokyo, Japan) in order to evaluate surface alterations.

\section{STATISTICAL ANALYSES}

The difference between the initial stage and the removal times of cones from the test solutions was evaluated with a Wilcoxon test. The differences between solutions were evaluated with Kruskal-Wallis; additionally, Bonferoniadjusted and Mann-Whitney-U tests were done to confirm the source of the difference. Significance level for all tests was set to $\mathrm{p}<0.05$.

\section{RESULTS}

The mean areas of the inhibition zone for the different microorganisms caused by four different solutions and a control solution for three different time periods are presented. Tables 1 and 2 show the differences between time periods.

\begin{tabular}{|llcccc}
\multicolumn{5}{c}{ Table 1: The median inhibition zones (in mm) } \\
\hline Groups & Solutions & Initial & 1 min & 5 mins & 10 mins \\
\hline S. aureus & $5.25 \% \mathrm{NaOCl}$ & 0 & 4 & 5 & 4 \\
& $2.5 \% \mathrm{NaOCl}$ & 0 & 2 & 3 & 3 \\
& $2 \% \mathrm{CHX}$ & 0 & 10 & 10 & 10 \\
& $0.05 \% \mathrm{Oct}$ & 0 & 2 & 2 & 3 \\
& $\mathrm{SSS}$ & 0 & 0 & 0 & 0 \\
E. faecalis & $5.25 \% \mathrm{NaOCl}$ & 0 & 3 & 5 & 4 \\
& $2.5 \% \mathrm{NaOCl}$ & 0 & 3 & 2 & 2 \\
& $2 \% \mathrm{CHX}$ & 0 & 8 & 8 & 8 \\
& $0.05 \% \mathrm{Oct}$ & 0 & 3 & 2 & 2 \\
& SSS & 0 & 0 & 0 & 0 \\
\hline
\end{tabular}

SSS: Sterile saline solution, Oct: Octenisept

\begin{tabular}{|c|c|c|c|c|c|c|c|}
\hline \multicolumn{8}{|c|}{ Table 2: Comparison between time periods } \\
\hline $\begin{array}{l}\text { Micro- } \\
\text { organisms }\end{array}$ & Solutions & $\begin{array}{l}\text { Initial } \\
1 \text { min }\end{array}$ & $\begin{array}{c}\text { Initial } \\
5 \\
\text { mins }\end{array}$ & $\begin{array}{c}\text { Initial } \\
10 \\
\text { mins }\end{array}$ & $\begin{array}{l}1-5 \\
\text { mins }\end{array}$ & $\begin{array}{l}1-10 \\
\text { mins }\end{array}$ & $\begin{array}{l}5-10 \\
\operatorname{mins}\end{array}$ \\
\hline \multirow[t]{5}{*}{ S. aureus } & $5.25 \% \mathrm{NaOCl}$ & * & * & * & $\varnothing$ & $\varnothing$ & * \\
\hline & $2.5 \% \mathrm{NaOCl}$ & * & * & * & $\varnothing$ & $\varnothing$ & $\varnothing$ \\
\hline & $2 \% \mathrm{CHX}$ & * & * & * & $\varnothing$ & $\varnothing$ & $\varnothing$ \\
\hline & $0.05 \%$ Oct & * & * & * & $\varnothing$ & * & * \\
\hline & SSS & $\varnothing$ & $\varnothing$ & $\varnothing$ & $\varnothing$ & $\varnothing$ & $\varnothing$ \\
\hline \multirow[t]{5}{*}{ E. faecalis } & $5.25 \% \mathrm{NaOCl}$ & * & * & * & * & $\varnothing$ & $\varnothing$ \\
\hline & $2.5 \% \mathrm{NaOCl}$ & * & * & * & $\varnothing$ & $\varnothing$ & $\varnothing$ \\
\hline & $2 \% \mathrm{CHX}$ & * & * & * & $\varnothing$ & $\varnothing$ & $\varnothing$ \\
\hline & $0.05 \%$ Oct & $\star$ & $\star$ & $\star$ & * & $\varnothing$ & $\varnothing$ \\
\hline & SSS & $\varnothing$ & $\varnothing$ & $\varnothing$ & $\varnothing$ & $\varnothing$ & $\varnothing$ \\
\hline
\end{tabular}

${ }^{*}: p<0.05, \varnothing$ : no significance, Oct: Octenisept, SSS: Sterile saline solution 
When the solutions are compared with each other in time intervals:

$\mathrm{NaOCl}(5.25 \%)$ is significantly more effective than $2.5 \%$ $\mathrm{NaOCl}$ or $0.05 \%$ octenisept against $S$. aureus when immersed for five minutes, and against $E$. faecalis for five or ten minutes of immersion ( $p<0.05)$. CHX $(2 \%)$ is significantly more effective than $5.25 \% \mathrm{NaOCl}$ or $2.5 \%$ $\mathrm{NaOCl}$ against $S$. aureus after five and ten minutes of immersion and against $E$. faecalis at all time periods ( $\mathrm{p}<$ 0.05). CHX (2\%) is more effective than $0.05 \%$ octenisept against both microorganisms at all time periods $(\mathrm{p}<0.05)$. Finally, there is no difference between $2.5 \% \mathrm{NaOCl}$ and $0.5 \%$ octenisept when compared in all situations ( $p>0.05)$.

None of the tested solutions showed any alteration on surface of gutta-percha points during selected time intervals (Figs 1A to D).

\section{DISCUSSION}

In this study, the residual antibacterial effect of different gutta-percha disinfectant solutions was evaluated against two bacteria. Since it was reported that $S$. aureus and E. faecalis were found to be the most resistant microorganisms to instrumentation and irrigation procedures, ${ }^{16,17}$ these bacteria were chosen for this study. Although facultative anaerobic cocci as S. aureus are seldom found in infected root canals despite the fact that they are normal inhabitants of saliva and the human skin, guttapercha cones can be easily contaminated during storage or if incorrectly manipulated. ${ }^{7,18}$

$\mathrm{NaOCl}$ is widely used in root canal treatments as an irrigant and at different concentrations for sterilization of gutta-percha against possible contamination. Using the direct contact method, it was shown that $5.25 \% \mathrm{NaOCl}$ eliminates most organisms within 15 seconds. ${ }^{19,20}$ In addition, $2.5 \% \mathrm{NaOCl}$ was found to be effective against all microorganisms except $E$. faecalis biofilm after five minutes. ${ }^{20}$

CHX (2\%) was also reported to be used either as an irrigant solution or as an intracanal medication. ${ }^{21} \mathrm{~A} 2 \% \mathrm{CHX}$ solution was found effective at 15 seconds to 2 hours in direct contact with infected gutta-percha cones. ${ }^{7}$ Although
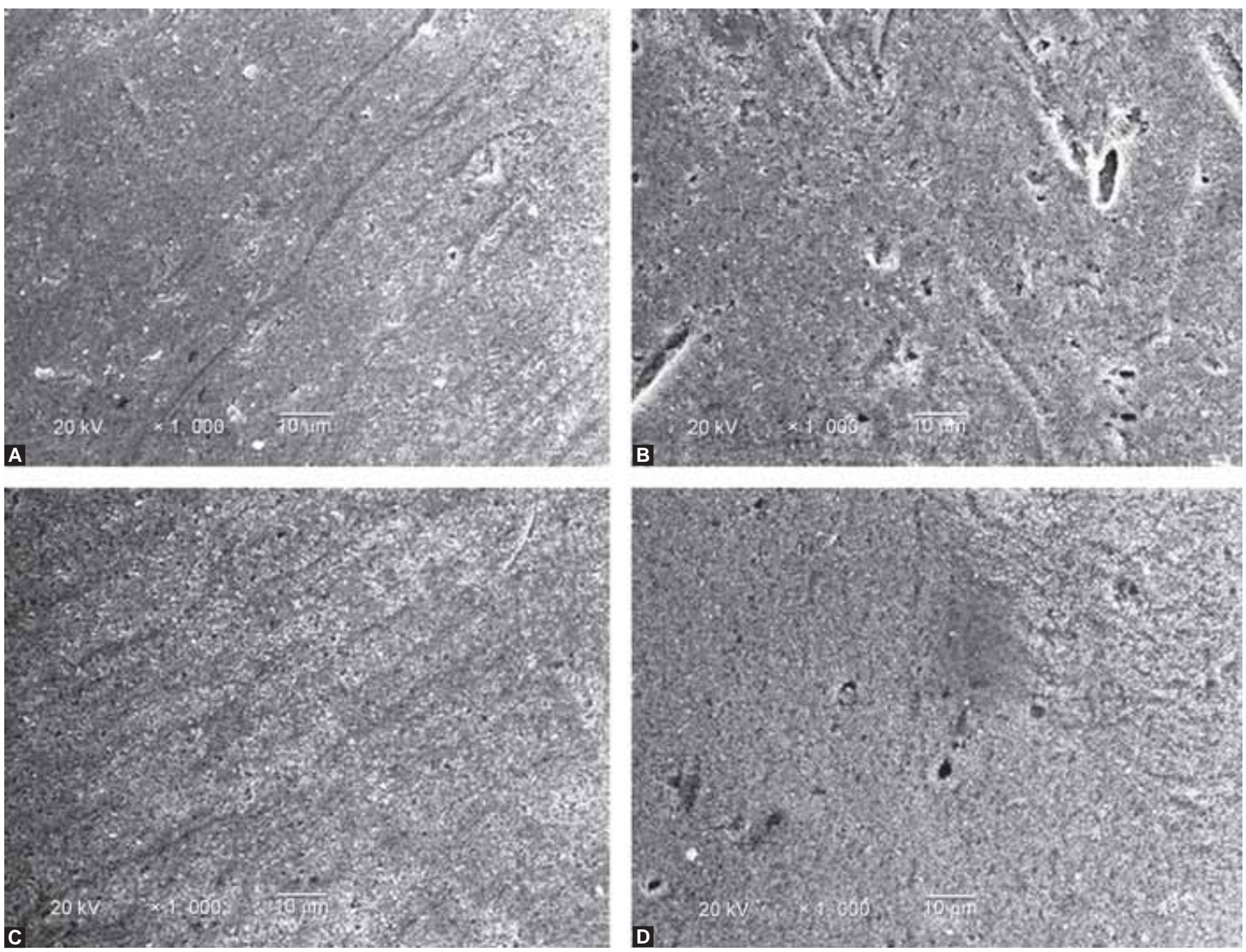

Figs 1A to D: Surface images with SEM, (A) control group, (B) 10 mins of $0.05 \%$ octenisept

(C) 10 mins of $5.25 \% \mathrm{NaOCl}$, (D) 10 mins of $2 \% \mathrm{CHX}$ 
several articles have reported that the residual microbial activity of CHX lasted from 48 hours to 28 days in a root canal when used as an irrigant, ${ }^{22-24}$ in this study, CHX was used as a gutta-percha disinfectant and was evaluated for residual activity on gutta-percha cones. There were also several studies about the use of CHX for sterilization of root canal filling materials, in which $\mathrm{CHX}$ was compared with $\mathrm{NaOCl}$ for activity against different microorganisms. ${ }^{7,11}$

Octenisept was demonstrated to have broad-spectrum antimicrobial effects against both Gram-positive and Gramnegative bacteria, fungi and several viral species, ${ }^{14}$ and the efficacy of octenidine was reported against dental plaqueassociated bacteria when compared with $\mathrm{CHX}{ }^{25,26}$ Octenisept was chosen as a test solution in this study after the publication of reports that it was used as a root canal dressing material and had antibacterial activity against E. faecalis in root canal and dentine after one minute. ${ }^{13}$

There are a few studies that evaluate the residual antimicrobial activity of the immersion of gutta-percha into different solutions. ${ }^{12}$ In this study, we showed that, for all time periods of immersion, $\mathrm{NaOCl}$ at all concentrations was effective in all time periods, but only $5.25 \% \mathrm{NaOCl}$ continued to affect $E$. faecalis after five or ten minutes of immersion and S. aureus only after five minutes. This may be because gauze does not provide a totally dry surface and because the efficiency of high concentrations of $\mathrm{NaOCl}$ may continue on moist surfaces of gutta-percha. The present study showed that $2 \% \mathrm{CHX}$ had the best residual antimicrobial effects against all tested microorganisms at all time periods. This continuing effect may be due to $\mathrm{CHX}$ coating gutta-percha with a thin film as it does when used as a mouth rinse, or it may be due to the remnants of $\mathrm{CHX}$ on gutta-percha. Although octenisept also had a residual effect against bacteria when compared with the initial effect, $5.25 \% \mathrm{NaOCl}$ and $2 \% \mathrm{CHX}$ were found to be more effective then octenisept, and there was no difference between $2.5 \%$ $\mathrm{NaOCl}$ and octenisept. Slow release of $\mathrm{CHX}$ and a high concentration of $\mathrm{NaOCl}$ may be the reasons for these results.

In the literature, there are some contradictory results related to the surface alterations. In a study Valois et $\mathrm{al}^{27}$ reported the surface alterations on gutta-percha cones even immersed in $\mathrm{NaOCl}$ in short time periods but Gomes et al ${ }^{12}$ did not mention any surface alteration of gutta-percha cones. The results of our study also supported the findings of Gomes et al.

Although we took clinical situations into consideration with respect to the time needed for immersion of guttapercha into solutions and in the selection of solutions, clinically, the effects of these solutions may change according to the root canal environment and root canal filling procedures.

\section{CONCLUSIONS AND CLINICAL SIGNIFICANCES}

- Although gutta-percha points are aseptic in their package, once opened and used, gutta-percha cones may be contaminated.

- In the limits of this study, immersion of gutta-percha into $2 \% \mathrm{CHX}$ for one minute was found the most effective method to eliminate the selected microorganisms.

\section{ACKNOWLEDGMENTS}

The authors thank to Gazi University, Faculty of Engineering, for assistance with using the SEM which was supported by Turkish Prime Ministry, State Planning Organisation Project 2001K120590.

\section{REFERENCES}

1. Seltzer S, Bender IB. Factors affecting successful repair after root canal therapy. J Am Dent Assoc 1963;67:651-62.

2. Dummer PMH. Root canal filling. In: Pitt Ford TR (Ed). Harty's Endodontics in Clinical Practice (4th ed). Wright, London 1997:123-53

3. Higgins JR, Newton CW, Palenik CJ. The use of paraformaldehyde powder for the sterile storage of gutta-percha cones. J Endod 1986;12:242-48.

4. Motta PG, de Figueiredo CBO, Maltos SM, Nicoli JR, Ribeiro Sobrinho AP, Maltos KL, Carvalhais HP. Efficacy of chemical sterilization and storage conditions of gutta-percha cones. Int Endod J 200134:435-39.

5. Montgomery S. Chemical decontamination of gutta-percha cones with polyvinylpyrrolidone-iodine. Oral Surg Oral Med Oral Pathol 1971;31:258-66.

6. Stabholz A, Stabholz A, Friedman S, Heling I, Sela MN. Efficiency of different chemical agents in decontamination of gutta-percha cones. Int Endod J 1987;20:211-16.

7. Gomes BP, Vianna ME, Matsumoto CU, Rossi Vde P, Zaia AA, Ferraz CC, Souza Filho FJ. Disinfection of guttapercha cones with chlorhexidine and sodium hypochlorite. Oral Surg Oral Med Oral Pathol Oral Radiol Endod 2005;100:512-17.

8. Özalp N, Ökte Z, Özçelik B. The rapid sterilization of guttapercha cones with sodium hypochlorite and glutaraldehyde. J Endod 2006;32:1202-04.

9. Senia AES, Marraro RV, Mitchell JL, Lewis AG, Thomas L. Rapid sterilization of gutta-percha cones with $5.25 \%$ of sodium hypochlorite. J Endod 1975;1:136-40.

10. Valois CRA, Silva LP, Azevedo RB. Effects of $2 \%$ chlorhexidine and $5.25 \%$ sodium hypochlorite on gutta-percha cones studied by atomic force microscopy. Int Endod J 2005;38:425-29.

11. Gomes BPFA, Ferraz CCR, Vianna ME, Berber VB, Teixeira FB, Souza-Filho FJ. In vitro antimicrobial activity of several concentrations of sodium hypochlorite and chlorhexidine gluconate in the elimination of Enterecoccus faecalis. Int Endod J 2001;34:424-28. 
12. Gomes BP, Berber VB, Montagner F, Sena NT, Zaia AA, Ferraz CC, Souza-Filho FJ. Residual effects and surface alterations in disinfected gutta-percha and resilon cones. J Endod 2007;33:948-51.

13. Tandjung L, Waltimo T, Hauser I, Heide P, Decker EM, Weiger R. Octenidine in root canal and dentine disinfection ex vivo. Int Endod J 2007;40:845-51.

14. Sedlock DM, Bailey DM. Microbicidal activity of octenidine hydrochloride, a new alkanediylbis (pyridine) germicidal agent. Antimicrob Agents Chemother 1985;28:786-90.

15. Sherertz RJ, Forman DM, Solomon DD. Efficacy of dicloxacillin-coated polyurethane catheters in preventing subcutaneous Staphylococcus aureus infection in mice. Antimicrob Agents Chemother 1989;33:1174-78.

16. Molander A, Reit C, Dahlen G, Kvist T. Microbiological status of root-filled teeth with apical periodontitis. Int Endod J 1998;31:1-7.

17. Sena NT, Gomes BP, Vianna ME, Berber VB, Zaia AA, Ferraz CC, Souza-Filho FJ. In vitro antimicrobial activity of sodium hypochlorite and chlorhexidine against selected singlespecies biofilms. Int Endod J 2006;39:878-85.

18. Sundqvist G. Ecology of the root canal flora. J Endod 1992;18: 427-30.

19. Spratt DA, Pratten J, Wilson M, Gulabivala K. An in vitro evaluation of the antimicrobial efficiacy of irrigants on biofilms of root canal isolates. Int Endod J 2001;34:300-07.

20. Vianna ME, Gomes BPFA, Berber VB, Zaia AA, Ferraz CC, de Souza-Filho FJ. In vitro evaluation of the antimicrobial activity of clorhexidine and sodium hypochlorite. Oral Surg Oral Med Oral Pathol Oral Radiol Endod 2004;97:79-84.

21. Gomes BP, Souza SF, Ferraz CC, Teixeira FB, Zaia AA, Valdrighi L, Souza-Filho FJ. Effectiveness of $2 \%$ chlorhexidine gel and calcium hydroxide against Enterococcus faecalis in bovine root dentine in vitro. Int Endod J 2003;36:267-75.

22. White RR, Hays GL, Janer LR. Residual antimicrobial activity after canal irrigation with chlorhexidine. J Endod 1997;23: 229-31.

23. Leonardo MR, Tanomaru Filho M, Silva LAB, Nelson Filho P, Bonifacio KC, Ito IY. In vivo antimicrobial activity of $2 \%$ chlorhexidine used as a root canal irrigating solution. J Endod 1999;25:167-71.
24. Mohammadi Z, Shahriari S. Residual antibacterial activity of chlorhexidine and MTAD in human root dentin in vitro. J Oral Sci 2008;50:63-67.

25. Slee AM, O`Connor JR. In vitro antiplaque activity of octenidine dihydrochloride (WIN 41464-2) against preformed plaques of selected oral plaque-forming microorganisms. Antimicrob Agents Chemother 1983;23:379-84.

26. Decker EM, Weiger R, Wiech I, Heide PE, Brecx M. Comparison of antiadhesive and antibacterial effects of antiseptics on Streptococcus sanguinis. Eur J Oral Sci 2003;111:144-48.

27. Valois CRA, Silva LP, Azevedo RB. Structural effects of sodium hypochlorite solutions on gutta-percha cones: Atomic force microscopy study. J Endod 2005;31:749-51.

\section{ABOUT THE AUTHORS}

\section{G Şahinkesen}

Department of Endodontics, Gulhane Military Medical Academy Dental Sciences Center, Etlik, Ankara, Turkey

\section{EA Oktay}

Department of Endodontics, Gulhane Military Medical Academy Dental Sciences Center, Etlik, Ankara, Turkey

\section{ÖEr}

Department of Endodontics, Faculty of Dentistry, University of Erciyes, Kayseri, Turkey

\section{Koçak}

\section{(Corresponding Author)}

Department of Endodontics, Faculty of Dentistry, University of Zonguldak Karaelmas, Esenkoy-Kozlu, 67600, Zonguldak Turkey Phone: 0903722613404, Fax: 0903722613403, e-mail: mmuratkocak@yahoo.com

\section{A Kiliç}

Department of Microbiology, Gulhane Military Medical Academy Etlik, Ankara, Turkey 